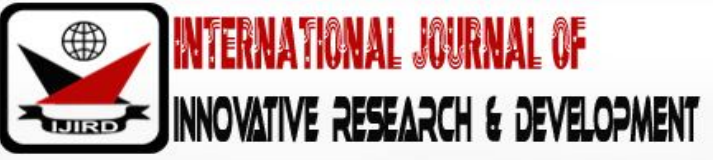

ISSN 2278 - 0211 (Online)

\section{Effect of Nitrogen-Fortified Rice Mill Waste on the Growth and Yield of Maize (Zee Mays) and Its Influence on Soil Chemical Properties in South Eastern Rainforest of Nigeria}

\author{
Thomas Ogon Ojikpong \\ Lecturer, Department of Agronomy, Cross River University of Technology, \\ Obubra Campus, Nigeria
}

\begin{abstract}
:
Organo-mineral nutrients sources are promising soil amendments for sustainable crop production in Nigeria. A field experiment was conducted at the Teaching and Research Farm of the Cross-River University of Technology Obubra during the 2016 cropping season. The objective of the study was to eradicate the effects of nitrogen amended Rice mill waste (RMW) on some soil chemical properties and yield of maize (Zee mays L.) the treatments consist of $10 \mathrm{ha}^{-1}$ Rice mill waste as control and 10ha- of rice mill waste amended with $10 \mathrm{KgNha}^{-1}, 20 \mathrm{KgNha}^{-1}, 30 \mathrm{Kg} \mathrm{Nha}^{-1}, 40 \mathrm{Kg} \mathrm{Nha}^{-1}, 50 \mathrm{KgNha}^{-1}$. The six treatments were replicated three times under RCBD with each experimental plot size measuring $4 \mathrm{~m} \times 3 \mathrm{~m}$. Result obtained showed that all the treatments including control increased the chemical properties of the soil over the initial soil properties including total $\mathrm{N}$, available $\mathrm{P}$, Som, $\mathrm{pH}$ and the exch. Cations of $\mathrm{Ca}_{2}+\mathrm{K}^{+}, \mathrm{Mg}^{2+} \mathrm{Na}^{+}$. $\mathrm{RMW}+40 \mathrm{Kg} \mathrm{N} /$ ha and $\mathrm{RMW} 50 \mathrm{KgN} /$ ha produced tallest plants, highest number of leaves per plant and largest leaf area of maize plants. RMW + $30 \mathrm{KgNha}^{-1}$, RMW $+40 \mathrm{Kg} \mathrm{Nha}{ }^{-1}$ and RMW $+50 \mathrm{Kg} \mathrm{Nha}{ }^{-1}$ produced highest number of seeds per cob, highest plant dry matter and highest grain yield per unit area of $2.61 \mathrm{t} /$ ha and $2.59 \mathrm{t} /$ ha respectively in 2016 and $2.63 \mathrm{t} / \mathrm{ha}$ and $2.62 \mathrm{t} /$ ha grain yield in 2017 while the least grain yield was obtained from the control ( $0.81 \mathrm{t} / \mathrm{ha}$ and $0.83 \mathrm{t} /$ ha respectively for 2016 and 2017). Rice mill waste amended with $30 \mathrm{Kg} \mathrm{N}$ ha $^{-1}$ is therefore recommended for optimum economic yield of maize in Obubra Rainforest soil and the improvement of soil chemical properties for sustainability.
\end{abstract}

Keywords: Rice Mill Waste (RMW), Organo-mineral, n-fertilizer, maize and rainforest

\section{Introduction}

Recycling of agricultural waste is a great resource for sustainable crop yields in Nigeria. Soils in the humid tropics are poor in organic matter and available nutrients, hence their productivity and sustainability decline over time when subjected to continuous cultivation (Zingore et al; 2003).

The maintenance of soil organic matter is the basis of sustainable crop production in Nigeria and the tropics in general (Oladipo et al; 2005). Monkwunye and Batiano, (2001) stated that tropical soils are generally low in organic matter, poorly buffered and low in CEC. Organic based fertilizers have been reported to increase crop yield as well as soil quality (Babalola and Olowokere, 2005). Although organic manures are bulky and low in nutrients content, Chiroma (1990) noted that, they are capable of valuable contribution to continuous demand of crop nutrients with the additional role of conditioning the soil physically for improved crop environment such as structure of soil, reduced bulk density, increase porosity and water and nutrients retention.

Rice mill waste (husk) abounds in rice growing and processing areas in bulk or large quantities with low nitrogen contents. The fortification of this waste will enhance faster mineralization for nutrients release and other organic products of decomposition including humus for soil physical properties improvement. Moreover, maize is a staple crop that requires relatively high soil fertility with regards to $\mathrm{N}$, $\mathrm{P}$, and $\mathrm{K}$ for sustainable yield.

\section{Materials and Methods}

Location: The study was carried out at the Teaching and Research Farm of the Cross-River University of Technology, Obubra Campus during the 2016 and 2017 cropping seasons on latitude $6^{0} 06^{\prime} \mathrm{N}$ and $8^{0} 18^{\prime} \mathrm{E}$ in the rainforest belt of Nigeria. Obubra is characterized by a mean annual rainfall of $2250 \mathrm{~mm}-2500 \mathrm{~mm}$ with an annual temperature range of $25^{\circ} \mathrm{C}-28^{\circ} \mathrm{C}$. 


\subsection{Experimental Design and Treatments}

The experiment was laid out in a Randomized Complete Block Design (RCBD) replicated three times. The treatments consisted of 10 t ha-1 $^{-1}$ rice mill waste which served as control, 10 tha-1 $^{-1}$ rice mill waste $+10 \mathrm{Kg} \mathrm{N} \mathrm{ha}^{-1}, 10 \mathrm{t} \mathrm{ha}^{-1}$ rice mill waste + $20 \mathrm{Kg} \mathrm{Nha}^{1}, 10 \mathrm{t} \mathrm{ha}^{-1}$ rice mill waste $+30 \mathrm{Kg} \mathrm{N} \mathrm{ha}^{-1}, 10 \mathrm{t} \mathrm{ha}^{-1}$ rice mill waste $+40 \mathrm{Kg} \mathrm{N} \mathrm{ha}^{-1}$ and $10 \mathrm{t} \mathrm{ha}^{-1}$ rice mill waste $+50 \mathrm{Kg}$ $\mathrm{Nha}^{-1}$.

\subsection{Experimental Material and Agronomic Practices}

The variety of maize used was OBA super 2 . The rice mill waste was obtained from the major rice mill in Obubra. This was weighed according to the treatment level and Nitrogen fertilizer rates added to the wastes accordingly. These were incorporated on prepared seed bed and allowed for four weeks before sowing of the maize seeds. The source of the inorganic nitrogen $(\mathrm{N})$ was Urea with $46 \%$ nitrogen.

\section{Data Collection}

\subsection{Soil Sampling and Processing}

At the commencement of the experiment, composite soil samples were collected at random points within the experiment plots which were bulked using soil auger at the 0 - $20 \mathrm{~cm}$ depth.

Post manuring and planting soil samples were collected from each treatment in the three replications and bulked. The samples were air dried and sieved through a $2 \mathrm{~mm}$ mesh ready for laboratory analysis.

\subsection{Plant Sampling}

A net plot of inner ridges for each treatment was used with five tagged plants for growth parameters. The grain yield for each net plot was extrapolated to yield in tonnes per hectare. Destructive sampling was used in each of the tagged plants in the net plot to determine plant dry matter and leaf nutrients content.

\subsection{Soil Analysis}

Routine analysis was conducted for the composite sample to determine the particle size distribution using the Bouyouchos Hydrometer method as outlined by Udo et al., (2009). Soil pH was determined using glass electrode pH meter and soil N by the Macro Kjeldahl apparatus as described by Udo et al, (2009).

Soil organic matter was analysed using the Walkley - Black wet Oxidation method as outlined by Page et al., (1982). The excess was titrated against ferrous sulphate. The organic carbon was then calculated using the relationship; \% Organic Carbon. $=\mathrm{N}(\mathrm{V} 1-\mathrm{V} 2) 03 \mathrm{f}$.

The $\%$ Organic matter in soil $=\%$ Organic Carbon $x$ 1.729. Soil phosphorus was determine using the Bray 1 method as described by Page et al., (198

\subsection{Statistical Analysis}

Analysis of variance (ANOVA) for RCBD was performed on the maize plant height and yield parameters using the computer software Genstat (Genstat 2005). FLSD was calculated on the means at P>0.05 to separate the means.

\section{Results and Discussion}

Results of pre - treatment soil properties and rice waste are presented in Tables 1 and 2 . The textural class of the soils for the 2016 and 2017 cropping is sandy loam with low organic matter content. The soils were also low in nitrogen, phosphorous, exchangeable cations and CEC. The soils were moderately acidic in reaction. The nitrogen $(\mathrm{N})$ content of the rice mill waste was low (0.94 \% in 2016 and $0.95 \%$ in 2017) but with a higher concentration of Calcium (Ca) with $2.21 \mathrm{cmol} / \mathrm{Kg}$ and $2.19 \mathrm{cmol} / \mathrm{Kg}$ respectively for 2016 and 2017 respectively.

The effects of amended rice mill waste on soil chemical properties are presented in Tables 3 and 4 . The pH of the soils at the end of the experiment was raised from the pre - treatment 5.3 in 2016 and 5.46 in 2017 by all doses of the amended rice mill waste.

The $\mathrm{pH}$ was raised from 5.3 to $5.6,6.1,6.2,6.2,6.1,5.9$ by RMW sole, RMW $+10 \mathrm{kgNha}^{-1}$, RMW $+20 \mathrm{kgNha}^{-1}$, RMW + $30 \mathrm{kgNha}^{-1}$, RMW $+40 \mathrm{kgNha}^{-1}$ and RMW $+50 \mathrm{kgNha}^{-1}$ respectively in 2016. This increase in $\mathrm{pH}$ followed the same trend in 2017.

Soil organic matter (SOM) at the end of the experiment was increased by all the treatments above the initial levels of the experimental site for both 2016 and 2017 cropping.This increase (Table 3) was in the order of RMW $+10 \mathrm{kgNha}^{-1}=\mathrm{RMW}+$ $0 \mathrm{kgNha}^{-1}=\mathrm{RMW}+20 \mathrm{kgNha}^{-1}>\mathrm{RMW}+30 \mathrm{kgNha}^{-1}>\mathrm{RMW}^{-}+40 \mathrm{kgNha}^{-1}=\mathrm{RMW}+50 \mathrm{kgNha}^{-1}$.

Total $\mathrm{N}$ of the soils at the end of the experiment was increased by the fortified rice mill waste over the unfortified and the pre - treatment soil samples. Total N increased in the order of RMW $+50 \mathrm{kgNha}^{-1}=\mathrm{RMW}+40 \mathrm{kgNha}^{-1}>\mathrm{RMW}+30 \mathrm{kgNha}-1=$ RMW + $20 \mathrm{kgNha}^{-1}>\mathrm{RMW}+10 \mathrm{kgNha}^{-1}>\mathrm{RMW}+0 \mathrm{kgNha}^{-1}$. (Table 3)

Available P (Table 3) was increased by the amendment over the control and the initial soil. The application of $\mathrm{N}$ fortified rice mill waste increased available $\mathrm{P}$ by all rates applied over the control. The available $\mathrm{P}$ in the control plots was higher than the initial soil available $P$. 
Results of exchangeable cations as influenced by the treatments (Table 4) show that the exchangeable cations of Ca, $\mathrm{K}$, $\mathrm{Mg}$ and $\mathrm{Na}$ at the end of the cropping did not differ among the treatments nor did they decrease compared with the initial soil exchangeable cations. Potassium and calcium however were increased above the initial soil level. RMW + $0 \mathrm{kgNha}^{-1}$ and RMW $+10 \mathrm{kgNha}^{-1}$ produced higher K and Ca values than the other amendments.

The pre-treatments low nutrients status and the moderately acidic reaction of these experimental sites is partly the characteristic feature of the rainforest soils due to high rainfall intensity and duration. This soil condition was reported by Chude (1998) and Harpstead (1973).

The increase in the $\mathrm{pH}$ of the post treatment and post-harvest soil reaction is an indication of the release of basic cations by this organic amendment to reduce activities of $\mathrm{H}^{+}$in soil.

This increase in soil pH due to application of organic amendments to soil has been reported by Olayinka et al (1998); Natsher and Schwetnmann (1991); Ojeniyi et al (1999); Ano and Agwu (2005).

The observed increase in soil organic matter (SOM) by the application of rice mill waste amended with $\mathrm{N}$ in the study has been documented (Brady and Weil 2002; Osundare 2004; Akanbi and Ojeniyi 2007). The lower SOMvalues in the higher inorganic $\mathrm{N}$ fortification amendments could be attributed to effect of inorganic nutrients that enhanced rapid mineralization of native SOMas earlier reported by Agboola (1990).

The higher total $\mathrm{N}$ content in the post-harvest soil was probably due to the enhanced mineralization of $\mathrm{N}$, particularly the higher inorganic $\mathrm{N}$ amendments. The lower $\mathrm{N}$ values in unfortified rice mill waste treated soils could be the depletion of native $\mathrm{N}$ by microbes to initiate the degradation of the rice waste which had a high $\mathrm{C} / \mathrm{N}$ ratio (Table 2)

This trend was reported by Eghball (2000); Abdallahi and N, Dayeganiye (2000).

The increase in available $\mathrm{P}$ that resulted from this soil amendment could be due to the increase in soil $\mathrm{pH}$ that can unlock fixed $\mathrm{P}$ in acidic soils. The use of organic manures and waste to raise soil $\mathrm{pH}$ and subsequent unlocking of $\mathrm{P}$ has been documented and all values were above the critical minimum level (Adeoye and Agloola, 1985).

The increase in the exchangeable $\mathrm{Ca}$ and $\mathrm{K}$ content in the post cropping soils and the non- decrease of $\mathrm{Mg}$ and $\mathrm{Na}$ compared with the pre-treatment soil values is an indication that the high $\mathrm{Ca}$ and $\mathrm{K}$ content of the of the rice mill waste mineralized and affected their concentration in the soils and even with the crop uptake of the cations there was no depletion. This observed increase in the exchangeable cations from organic waste application individually or in combination with inorganic fertilizers has been documented (Olanyika, 1990; Odedina et al 2007; Ayeni, 2010).

\subsection{Growth, Yield and Yield Components of Maize}

Result of growth, yield and yield components of maize as influenced by $\mathrm{N}$ fortified rice mill waste is presented in Tables 5, 6 and 7.

The application of $\mathrm{N}$ amended rice mill wastes significantly $(\mathrm{P}<0.05)$ increased the growth, yield and yield components of maize (Tables 5, 6 and7). The amendments of rice mill waste (rice husk) with inorganic N fertilizer significantly increased the plant height, number of leaves and leaf nutrients content. RMW $+40 \mathrm{Kg} \mathrm{N} /$ ha and RMW $+50 \mathrm{Kg} \mathrm{N} /$ ha produced tallest plants ( $243.41 \mathrm{~cm}$ and $248.32 \mathrm{~cm}$ respectively in 2016 and $253.21 \mathrm{~cm}$ and $251.13 \mathrm{~cm}$ respectively in 2017 ). RMW +40 $\mathrm{Kg} \mathrm{N} /$ ha and RMW $+50 \mathrm{Kg} \mathrm{N} /$ ha produced largest leaf area of maize plants $(810.42 \mathrm{~cm} 3$ and $809.53 \mathrm{~cm} 3$ respectively in 2016 and $788.41 \mathrm{~cm} 3$ and $789.43 \mathrm{~cm} 3$ respectively in 2017 (Table 5). The leaf N, P and $\mathrm{K}$ nutrients content was increased significantly by application of RMW $+40 \mathrm{Kg} \mathrm{N} /$ ha and RMW $+50 \mathrm{Kg} \mathrm{N} /$ ha above the other rates and the least nutrients concentration was in the control where rice mill waste was applied sole (Table 6). The application of the amended rice mill waste significantly increased number of seeds per cob, shoot dry matter and grain yield up to $30 \mathrm{kgNha}^{-1}$ and subsequently increasing these parameters marginally up to $50 \mathrm{kgNha}^{-1}$ (Table 7)

The increase in the yield and yield components of maize was in the order of $30 \mathrm{kgNha}^{-1}=40 \mathrm{kgNha}^{-1}=50 \mathrm{kgNha}^{-1}>20$ $\mathrm{kgNha}^{-1}>10 \mathrm{kgNha}^{-1}>0 \mathrm{kgNha}^{-1}$ (Table 7).

The increase in $\mathrm{pH}, \mathrm{SOM}$, total $\mathrm{N}$, available $\mathrm{P}$ and exchangeable cations due to the application of the amended rice mill waste could have manifested in the crop performance. This growth and yield results of this experiment agrees with the assertion of Ojeniyi et al (1999) where they observed highest maize yield from organo-mineral fertilizer. A combination of organic and inorganic fertilizers resulted in increased growth and yield of maize (Ayoola and Makinde, 2007; Dania et al; 2012). The high concentration of N, P and K in the leaf of maize in this study due to the amendment of rice mill waste agrees with the findings of Lawal et al., (2010) who reported higher uptake of NPK from organo-mineral fertilizer by yam. The low yield of maize in the control (RMW $+0 \mathrm{KgNha}^{-1}$ ) was probably due to the carbonaceous rice husk that slowed down the rate of mineralization of that amendment as earlier stated by Rajcan (1999).

\section{Conclusion}

The amendment of rice mill waste with inorganic Nitrogen fertilizer was found to be efficient in increasing soil nutrients status of total $\mathrm{N}$, available $\mathrm{P}$, organic matter and $\mathrm{Ca}$ as well as exchangeable cations of $\mathrm{K}, \mathrm{Mg}$, $\mathrm{Ca}$ and $\mathrm{Na}$ and ultimately increased yield and yield components of maize. The fertilization of this rice waste with $30 \mathrm{~kg} \mathrm{Nha}^{-1}{ }^{1}$ economical for the optimum yield of maize and improvement of soil chemical properties in this agro ecological zone. 


\section{References}

i. Abdallahi, M M. and N' Dayegamiye.A (2000). Effect of green manures on soil physical and biological properties and on wheat (Triticumaestivum) yield and N uptake. Canadian J. of Soil Science 80:81-90.

ii. Adeoye, G. O. and Agboola A. A. (1985). Critical levels for soil pH, available P, K, $2 \mathrm{n}$ and Mn in sedimentary soil of southerneatern Nigeria fertilizer research $6 \backslash$; 65-71.

iii. Agboola ,A.A. (1990) organic matter and soil fertility management in the humid tropics of Africa.In : proceeding of the third regional workshop of the Africa land programme held at Antannarivo, Madagascar, January 9-15, 1990.

iv. Akanbi, O. S. and S. O. Ojeniyi (2007), Effect of Siam weed mulch on soil properties and performance of yam in Southwest Nigeria. Nigerian Journal of Soil Science 17: 120-125.

v. Ano, A.O and AgwuJ.A. (2005) Effects of animal manures on selected soil properties (1) Nigeria Journal of Soil Science $15: 14-19$

vi. Ayemi, L.S. (2010): Effect of combined cocoa pod ash and NPK on soil properties, nutrient uptake and yield of maize (Zea may L). Journal of American Science 6(3).79-84.

vii. Ayoola, O. T. and Makinde, E. A. (2007). Complementary organic and inorganic fertilizer application influence on growth and yield of cassava/ maize/melon intercrop with relayed cowpea. Australian Journal of Basic and Applied Science 1(3): 187-192.

viii. Babalola, O. A. and Olowokere F. A. (2005) Contributions of legume Green manure to soil fertility, and maize growth.Proceeding $1^{\text {st }}$ national conference on organic agriculture, UNAAB, Abeoleute, Nigeria 25 - 28October, 2005, 17 93-98.

ix. Brady, N.C. and Weil, R.R. (2002) Nature and properties of soils (13 thEdition) Pearson Educational Publishers, New Delhi India.

x. Chude, V.O. (1998) Understanding Nigeria Soils and their Fertility Management for Sustainable Agriculture. Inaugural Lecture delivered at ABU, Zaria on Thursday Nov. 26. 1998 Inaugural lecture series 13.

xi. Dania, S. O. Fagbola, O. and Isitekhale, H. H. E. (2012).Effect of Sawdust and organic mineral fertilizer and their residual effect on the yield of maize on degraded soil Pakistan Journal of Agricultural Science Vol 49 (1) 61-66.

xii. Eghball B (2000). Nitrogen mineralization from field applied beef cattle Feedlot manure or compost. Soil Sci. Soc. of America J. 64:2024-2030.

xiii. Genstat (2005).Genstat Release 4.24DE (PC/ Windows XP) Copy right 2005, Laves Agricultural Trust (Rothamstal) Experimental Station) Discuringedt. 2

xiv. Harpstead, M.T. (1973) The classification of some Nigerian soils. Soil science 116:437-442

xv. Lawal, I. O., Adeoye, G. O., Asiedu, R. and Ojeniyi, S.O. (2010) Effect of Organo-Mineral fertilizer on Yield and Nutrients Uptake of White Yam(DioscorearotundataPoir.) in Ibadan, South Western Nigeria. Proceedings of the 34th Annual Conference of the Soil Science Society of Nigeria: $173-182$.

xvi. Mokuwunte, U. and Bations A, (20010, Mating the Phosphorus needs of the soils and crops of West Africa the role of indigenous phosphates rocks integrated plants nutrients management in sub-saharan Africa from concept to practice Ed. CAB international M209-224.

xvii. Natschner,l. and Schwetmann,U. (1991) Proton buffering in organic horizons of acid forest soils. Geoderma 48: 93-106.

xviii. Odedina, S. A. Ojeniyi S. O. and Anodun MA (2007). Effect of Agroindmatrial vaster on nutrients status and performances of tomato global Journal Environmental Research 1(1): 18-20.

xix. Oladipo, O. G., Aduayi, E. A. and Olayinka A. (2005).Effect of organic amendments on microbial activity, N and P mineralization in an Alfidol.Environmental Management Journal 2: 30-40.

xx. Olayinka A. Adetunji A. and Adebayo A. (1998).Effect of organic amendments on nodulation and nitrogen fixation by cowpea Journal of Plant Nutrition 21 (11) 2455-2464.

xxi. Oleynka A. (1990). Effect of poultry manure, corn straw and saw dust on plant growth and soil chemical properties Journal of Agriculture 12(1) 36 -44.

xxii. Osundare, B. (2004), Effect of different companion crops and fertilizer Types on soil Nutrient Dynamics and performance of cassava. Nigerian Journal of soil science 14: 13-17.

xxiii. Page, A. L., R. H. Miller, and D. R. Keeney (1982). Methods of soil Analysis part 2. Chemical and microbiological properties. American Society of Agronomy, Madison $55 \mathrm{pp}$

xxiv. Raycan, I. and Jollen, M. (1999). Source: Sink ratio and leaf Effect of poultry manure, corn straw and sawdust senescence in maize. In organic matter accumulation and partitioning during grain filling. Field crops research. An Armsterdom60 (2) 245 - 253.

xxv. Udo, E. J., T. O. Ibia, J. O. Ogunwale, A. O. Ano and I. Esu (2009), Manual of Soil, Plant and Water Analysis, 183pp., Sibon Books Ltd. Lagos.

xxvi. Zingore, S., Murwira, H.K., Delve R.J. and Giller,K.E. (2007) Soil type, historical management and current resource allocation: three dimensions regulating variability of maize yields and nutrients use efficiency on African small holder farms. Field Crops Research, 101, 296 -305. 


\begin{tabular}{|c|c|c|}
\hline Parameter & 2016 & 2017 \\
\hline Sand $(\mathrm{g} / \mathrm{kg})$ & 853 & 797 \\
\hline Silt (g/ kg) & 79 & 106 \\
\hline Clay $(\mathrm{g} / \mathrm{kg})$ & 68 & 98 \\
\hline Texture class & $\mathrm{S} / \mathrm{L}$ & $\mathrm{S} / \mathrm{N}$ \\
\hline pH(water) & 5.30 & 5.46 \\
\hline $\mathrm{pH}(\mathrm{KCL})$ & 4.30 & 4.42 \\
\hline Organic matter (\%) & 1.26 & 1.34 \\
\hline Total nitrogen $(\mathrm{g} / \mathrm{kg})$ & 0.8 & 0.9 \\
\hline Available P (mg/ kg) & 3.4 & 4.1 \\
\hline Exch. Ca $\left(\mathrm{cmol} \mathrm{kg}^{-1}\right)$ & 2.60 & 2.52 \\
\hline Exchange. $\mathrm{Mg}\left(\mathrm{cmol} \mathrm{kg}^{-1}\right)$ & 0.22 & 0.21 \\
\hline Exchange. $\mathrm{Mg}\left(\mathrm{cmol} \mathrm{kg}^{-1}\right)$ & 1.01 & 1.20 \\
\hline Exchange $\mathrm{Na}\left(\mathrm{cmol} \mathrm{kg}^{-1}\right)$ & 0.17 & 0.18 \\
\hline Exchange. Acidity & 2.75 & 2.73 \\
\hline $\mathrm{CEC}\left(\mathrm{cmol} \mathrm{kg}^{-1}\right)$ & 1.8 & 6.21 \\
\hline
\end{tabular}

Table 1: Pre Cropping Soil Physical and Chemical Properties at the Experimental Site

\begin{tabular}{|c|c|c|}
\hline \multirow{2}{*}{ Properties } & \multicolumn{2}{|c|}{ Rice Mill Waste (RMW) } \\
\cline { 2 - 3 } & $\mathbf{2 0 1 6}$ & $\mathbf{2 0 1 7}$ \\
\hline Total Nitrogen $(0 \%)$ & 0.94 & 0.95 \\
\hline Total phosphorus $\left(\mathrm{m}_{\mathrm{g}} / \mathrm{k}_{\mathrm{g}}\right)$ & 0.92 & 0.92 \\
\hline Total potassium $\left(\mathrm{cmol} / \mathrm{K}_{\mathrm{g}}\right)$ & 0.38 & 0.37 \\
\hline Calcium $\left(\mathrm{cmol} / \mathrm{k}_{\mathrm{g}}\right)$ & 2.21 & 2.19 \\
\hline Magnesium $\left(\mathrm{cmol} / \mathrm{k}_{\mathrm{g}}\right)$ & 0.53 & 0.61 \\
\hline Sodium $\left(\mathrm{cmol} / \mathrm{k}_{\mathrm{g}}\right)$ & 0.21 & 0.22 \\
\hline Org.carbon $(\%)$ & 38.1 & 38.41 \\
\hline C:N Ratio & 40.53 & 40.43 \\
\hline
\end{tabular}

Table 2: Nutrients Composition of the Rice Mill Waste

\begin{tabular}{|c|c|c|c|c|}
\hline Treatment & pH & OM (\%) & TOTAL N(\%) & Av. $\mathbf{P}(\mathbf{M g} / \mathbf{K g})$ \\
\hline $\mathrm{RMW}+0 \mathrm{Kg}_{\mathrm{Nha}^{-1}}{ }^{-1}$ & 6.2 & 1.62 & 0.08 & 21.2 \\
\hline RMW +10kg Nha-1 & 6.1 & 1.84 & 0.10 & 23.1 \\
\hline RMW+20Kg Nha-1 & 6.2 & 1.79 & 0.09 & 24.3 \\
\hline RMW+30KgNha-1 & 6.3 & 1.86 & 0.11 & 23.1 \\
\hline RMW+40KgNha-1 & 6.3 & 1.85 & 0.11 & 22.1 \\
\hline RMW+50 KgNha -1 & 6.4 & 1.83 & 0.13 & 21.4 \\
\hline \multicolumn{5}{|c|}{2017} \\
\hline $\mathrm{RMW}+0 \mathrm{Kg}_{\mathrm{Nha}^{-1}}$ & 6.3 & 1.61 & 0.07 & 9.62 \\
\hline RMW +10kg Nha-1 & 6.2 & 1.78 & 0.11 & 20.21 \\
\hline RMW+20Kg Nha-1 & 6.4 & 1.88 & 0.10 & 24.21 \\
\hline RMW+30KgNha-1 & 6.2 & 1.87 & 0.12 & 22.31 \\
\hline RMW+40KgNha-1 & 6.4 & 1.89 & 0.11 & 22.10 \\
\hline RMW+50 KgNha-1 & 6.3 & 1.81 & 0.13 & 21.40 \\
\hline
\end{tabular}

Table 3: Soil Ph, Organic Matter, Nitrogen and Available Phosphorus at the End of Cropping 


\begin{tabular}{|c|c|c|c|c|}
\hline Treatment & $\mathbf{K}$ & Ca & Mg & $\mathrm{Na}$ \\
\hline RMW +0Kg ${ }_{\mathrm{Nha}^{-1}}$ & 0.51 & 3.34 & 2.01 & 0.12 \\
\hline RMW +10Kg Nha-1 & 0.41 & 3.29 & 2.12 & 0.08 \\
\hline RMW $+20 \mathrm{Kg} \mathrm{Nha}-1$ & 0.38 & 3.58 & 1.88 & 0.10 \\
\hline RMW+30KgNha -1 & 0.37 & 3.61 & 1.89 & 0.11 \\
\hline RMW +40 KgNha-1 & 0.41 & 3.55 & 1.85 & 0.08 \\
\hline RMW +50 KgNha-1 & 0.43 & 3.62 & 1.79 & 0.09 \\
\hline
\end{tabular}

Table 4: Exchangeable Cations of the Soil at the End of the Cropping $(\mathrm{Cmol} / \mathrm{Kg})$

\begin{tabular}{|c|c|c|c|}
\hline \multicolumn{4}{|c|}{2016} \\
\hline Treatment & Plant Height $(\mathrm{cm})$ & Number of leaves & Leaf Area $\left(\mathrm{cm}^{3}\right)$ \\
\hline RMW +0 Kg N ha-1 & 168.02 & 11.32 & 632.10 \\
\hline RMW +10 Kg N ha-1 & 201.21 & 12.21 & 739.61 \\
\hline $\mathrm{RMW}+20 \mathrm{Kg} \mathrm{N} \mathrm{ha}{ }^{-1}$ & 211.24 & 11.80 & 746.34 \\
\hline RMW $+30 \mathrm{Kg} \mathrm{N} \mathrm{ha}-1$ & 225.31 & 12.40 & 760.21 \\
\hline RMW $+40 \mathrm{Kg} \mathrm{N} \mathrm{ha}-1$ & 243.41 & 13.53 & 810.42 \\
\hline RMW $+50 \mathrm{Kg} \mathrm{N} \mathrm{ha-1}$ & 248.32 & 13.42 & 809.53 \\
\hline FLSD $(<0.05)$ & 18.42 & 0.86 & 16.11 \\
\hline \multicolumn{4}{|c|}{2017} \\
\hline RMW +0Kg N ha-1 & 167.50 & 10.55 & 620.45 \\
\hline RMW +10 Kg N ha-1 & 208.41 & 12.41 & 698.42 \\
\hline RMW +20 Kg N ha-1 & 218.21 & 12.56 & 709.34 \\
\hline RMW $+30 \mathrm{Kg} \mathrm{N} \mathrm{ha-1}$ & 231.10 & 13.10 & 732.40 \\
\hline RMW +40Kg N ha-1 & 253.21 & 13.84 & 788.41 \\
\hline $\mathrm{RMW}+50 \mathrm{Kg} \mathrm{N} \mathrm{ha}-1$ & 251.13 & 13.52 & 789.43 \\
\hline FLSD $(<0.05)$ & 17.20 & 0.94 & 15.34 \\
\hline
\end{tabular}

Table 5: Maize Plant Height, Number of Leaves and Leaf Area as Affected by Nitrogen Fortified Rice Waste

\begin{tabular}{|c|c|c|c|}
\hline Treatment & $\mathbf{N}$ & $\mathbf{P}$ & $\mathbf{K}$ \\
\hline \multicolumn{4}{|c|}{2016} \\
\hline RMW +0 Kg N ha-1 & 2.24 & 0.42 & 0.74 \\
\hline RMW +10Kg N ha-1 & 2.65 & 0.48 & 0.79 \\
\hline RMW +20Kg N ha-1 & 2.78 & 0.52 & 0.85 \\
\hline RMW +30Kg N ha-1 & 3.21 & 0.58 & 0.84 \\
\hline RMW +40Kg N ha-1 & 3.80 & 0.62 & 0.91 \\
\hline RMW +50Kg N ha-1 & 4.42 & 0.66 & 0.94 \\
\hline FLSD $(<0.05)$ & 0.19 & 0.08 & 0.06 \\
\hline \multicolumn{4}{|c|}{2017} \\
\hline RMW +0 Kg N ha-1 & 2.31 & 0.40 & 0.73 \\
\hline RMW +10Kg N ha-1 & 2.64 & 0.49 & 0.80 \\
\hline RMW +20Kg N ha-1 & 2.88 & 0.50 & 0.83 \\
\hline RMW +30Kg N ha-1 & 3.35 & 0.58 & 0.85 \\
\hline RMW +40Kg N ha-1 & 3.72 & 0.65 & 0.91 \\
\hline RMW +50Kg N ha-1 & 4.64 & 0.66 & 0.92 \\
\hline FLSD $(<0.05)$ & 0.78 & 0.11 & 0.08 \\
\hline
\end{tabular}

Table 6: Leaf Nutrient of Maize as Affected by Application of Amended Rice Waste

\begin{tabular}{|c|c|c|c|}
\hline Treatment & No. of seeds per cob & $\begin{array}{c}\text { Dry matter } \\
\text { g/ plant }\end{array}$ & Grain yield t/ ha \\
\hline RMW +0 $\mathrm{Kg} \mathrm{N} \mathrm{ha}^{-1}$ & 308 & 6.42 & 0.81 \\
\hline $\mathrm{RMW}+10 \mathrm{Kg} \mathrm{Nha}^{-1}$ & 319 & 7.21 & 1.18 \\
\hline $\mathrm{RMW}+20 \mathrm{Kg} \mathrm{Nha}^{-1}$ & 382 & 7.42 & 2.42 \\
\hline $\mathrm{RMW}+30 \mathrm{Kg} \mathrm{Nha}^{-1}$ & 400 & 8.22 & 2.54 \\
\hline $\mathrm{RMW}+40 \mathrm{Kg} \mathrm{Nha}^{-1}$ & 398 & 8.26 & 2.61 \\
\hline RMW +50Kg N ha- & 401 & 8.26 & 2.59 \\
\hline FLSD $(<0.05)$ & 9.41 & 0.61 & 0.08 \\
\hline
\end{tabular}


2017

\begin{tabular}{|c|c|c|c|}
\hline Treatment & No. of seeds per cob & $\begin{array}{c}\text { Dry matter } \\
\text { g/ plant }\end{array}$ & Grain yield $\mathrm{t} / \mathrm{ha}$ \\
\hline RMW +0 Kg N ha-1 & 305 & 6.51 & 0.79 \\
\hline RMW +10 Kg N ha-1 & 324 & 7.40 & 1.20 \\
\hline RMW +20Kg N ha-1 & 389 & 7.48 & 2.30 \\
\hline RMW +30Kg N ha-1 & 403 & 8.21 & 2.58 \\
\hline RMW $+40 \mathrm{Kg} \mathrm{N} \mathrm{ha}^{-1}$ & 402 & 8.26 & 2.63 \\
\hline RMW +50Kg N ha-1 & 403 & 8.30 & 2.62 \\
\hline FLSD $(<0.05)$ & 9.62 & 0.10 & 0.09 \\
\hline
\end{tabular}

Table 7: Yield and Yield Components of Maize as Influenced by Nitrogen Amended Rice Mill Waste Key: RMW - Rice Mill Waste 
